\title{
Stability analysis of a dike constructed of anthropogenic materials
}

\author{
Andrzej Danilewicz ${ }^{1, *}$ \\ ${ }^{1}$ Gdansk University of Technology, Faculty of Civil and Environmental Engineering, Poland
}

\begin{abstract}
Numerical analyses of stability are presented for a hypothetical dikes constructed of dredged materials and bottom ash, in varying proportions. The paper is related to the international research project DredgDikes, which focused on the use of anthropogenic materials in dikes construction and flood protection. The aim of this project was to investigate the possibility of using anthropogenic materials from rivers and sea dredging and coal combustion products in dikes construction. The influence of different proportions of ash and dredged materials on the stability of dike is discussed. Mechanical and hydraulic parameters of various dredged material-ash mixtures are based on the results of laboratory and field tests performed in DredgDikes project. Numerical calculations are carried out using geotechnical software Plaxis. Cementation phenomenon and its effect on the performance of ash and dredged material mixtures is discussed.
\end{abstract}

\section{Introduction}

A dike is a construction made to prevent flooding, regulate river course or protect land against the sea. The design of a dike cross-section, cubage and high depends on the local variation in water levels. The flood protection in Poland is regulated under the Water Law [1] and technical requirements of dikes and other flood protection structures are defined in a ministerial directive [2]. Generally local materials are used to construct dike, but anthropogenic materials like sediments removed from rivers and sea during dredging works and also coal combustion products can be used under previous geotechnical supervision. Dredged materials are natural and integral components of the ecosystem. Coal combustion products (CCPs) are by-products of coal-fired power plants. The scope of the international project called DredgDikes was to propose how to plan and build dikes with the use of ripened dredged materials, coal combustion products and geosynthetics [3]. Dredged materials (and CCPs as well) are considered as a waste according to European Waste Catalogue [4]. Well grained dredged materials and CCPs have been used before in landscaping as well as other recultivation projects with good geotechnical experience. CCPs are also widely used in road constructions (especially in Poland).

The use of CCPs and dredged materials was a new idea in DredgDikes project. Stability mechanisms differ from dike types [7]. The stability of a dike slopes is one of the main

*Corresponding author: adanilew@pg.gda.pl 
issue to be taken under account during engineering design. During this analysis the dike and subsoil have to be investigated according to EC7 [5] and national recommendations [6].

\section{Test dike description}

During the DredgDikes Project two dikes were constructed - one in Rostock in Germany and the other one in Trzcińsko, near Gdańsk in Poland (see Fig. 1.). One of the main scope of polish part of the project was to investigate the possibility of using mixed dredge materials with coal combustion products for river dikes constructing. For this part of the project, the dredge material from the bottom of Vistula river was adopted. As a CCPs the fly ash from nearest Gdańsk power plant was used.

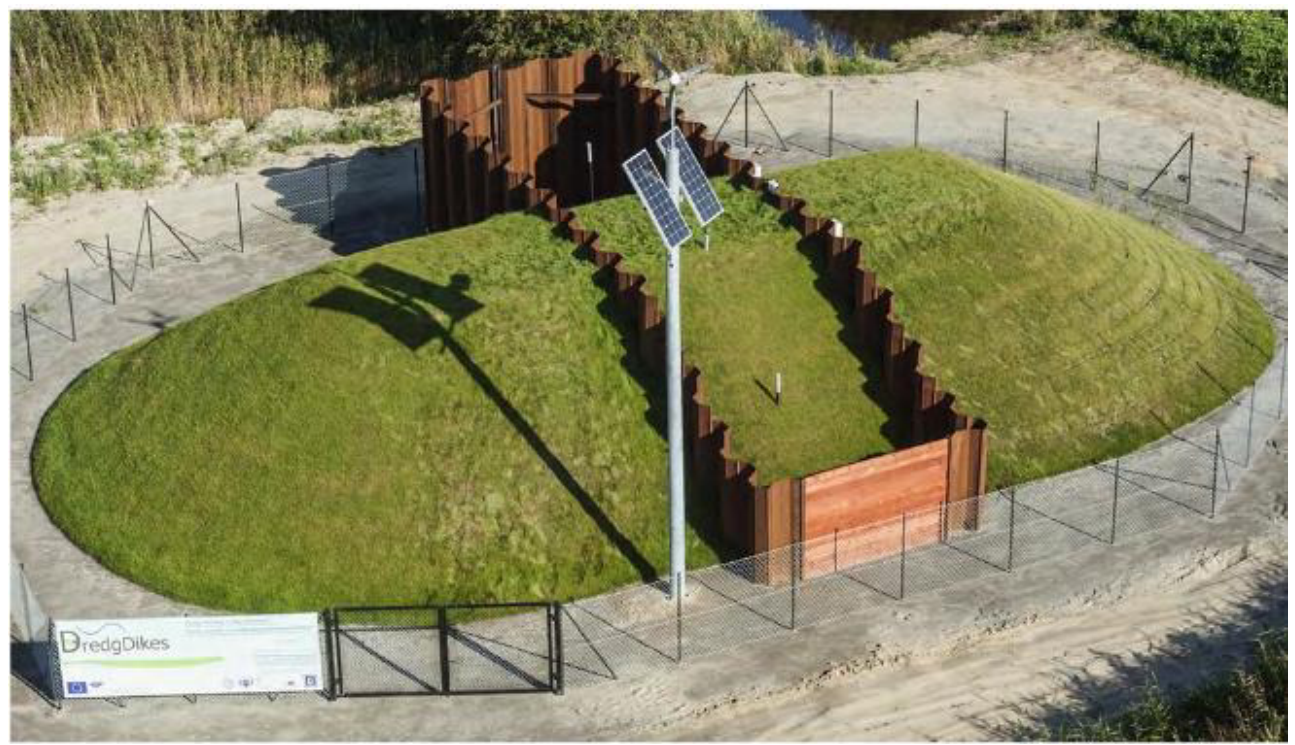

Fig. 1. Test dike in Trzcińsko - near Gdańsk [8].

The construction process of dike in Trzcińsko was ended in May 2012. The dike is $3 \mathrm{~m}$ high with inclination 1:2. The dike body is built from dredged material and compacted bottom ash mixture. As a result of preliminary studies, the construction material for the dike body consists of $30 \%$ of dredged material and $70 \%$ of ash. The dike is built on the compacted clay for environmental isolation. The inner side of the dike is covered with Tefra material - commercial mix of fly-ash and sand. The water level can be maintained about 2.5 meters above the ground level. The phreatic line for steady state flow was measured at elevation $1.62 \mathrm{~m}$. The dimensions of the test dike are presented in Fig. 2.

\subsection{Laboratory tests}

The parameters of soil layers used for the test dike construction was investigated in laboratory during the project and published in [9] (see Tab. 1). The series of laboratory tests have determinated mechanical parameters and physical properties of the clay and dredged material-ash bottom mixture. To obtain internal friction angle and cohesion direct shear tests were performed. Permeability coefficients were obtained for the different mixtures as well. 


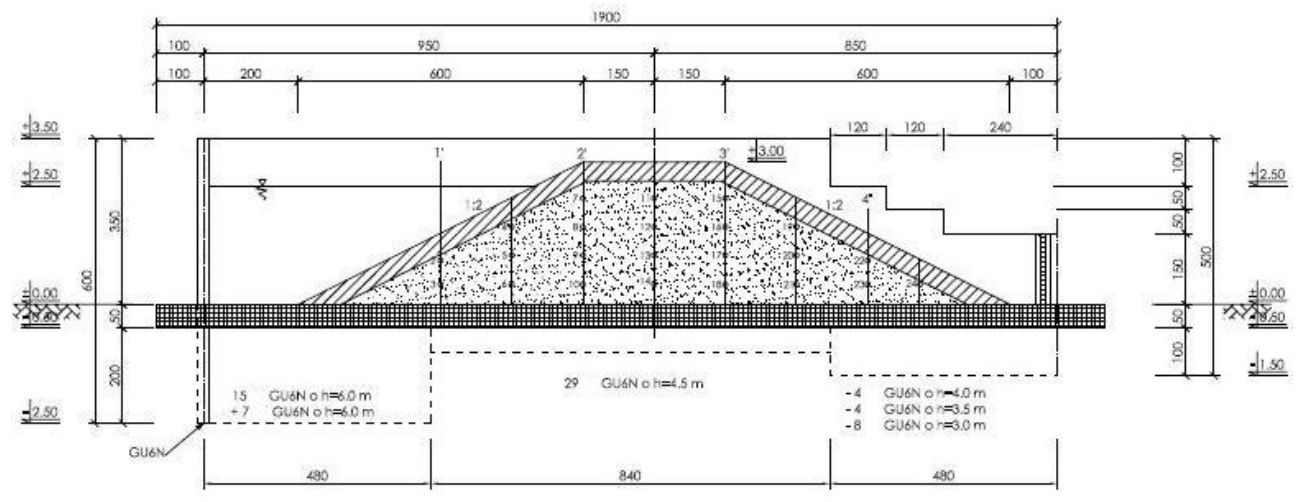

Fig. 2. Cross section of the polish test dike [8].

Table 1. Geotechnical parameters for clay and Tefra layer [9].

\begin{tabular}{|c|c|c|c|}
\hline & & Clay & Tefra \\
\hline unit weight & {$\left[\mathrm{kN} / \mathrm{m}^{3}\right]$} & 18 & 16 \\
\hline saturated unit weight & {$\left[\mathrm{kN} / \mathrm{m}^{3}\right]$} & 21 & 20 \\
\hline $\begin{array}{c}\text { permeability } \\
\text { coefficient }\end{array}$ & {$[\mathrm{m} / \mathrm{s}]$} & $1 \mathrm{E}-7$ & $1 \mathrm{E}-7$ \\
\hline undrained shear & {$[\mathrm{kPa}]$} & 50 & 30 \\
\hline effective cohesion & {$[\mathrm{kPa}]$} & 30 & 50 \\
\hline $\begin{array}{c}\text { effective angle of } \\
\text { friction }\end{array}$ & {$\left[{ }^{\circ}\right]$} & 25 & 20 \\
\hline Young's module & {$[\mathrm{MPa}]$} & 15 & 30 \\
\hline Poisson's ratio & {$[-]$} & 0,35 & 0,25 \\
\hline
\end{tabular}

\subsection{Mixture parameters}

One of the goals in this tests was to choose the optimum dredged material-CCPs mixture ratio to be applied in field test. The mixture with $70 \%$ content of dredged sand from Vistula river mouth and 30\% of bottom ash from EC Gdańsk power plant was chosen. Obtained values with their interpolation are presented in Fig. 3. according to proposition given in [10].

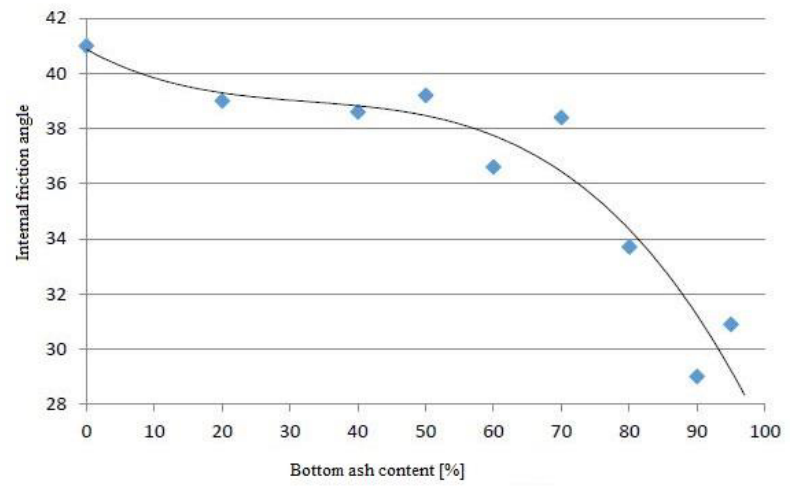

Fig. 3. Internal friction angle for various mixtures [10].

According to recommendation from DredgDikes project only mixtures with unit weight higher than $12 \mathrm{kN} / \mathrm{m}^{3}$ should be used for the dike construction, so mixtures $90 / 10$ and $100 / 0$ 
are skipped in further considerations. Some geotechnical properties for different mixtures are presented in Table 2 .

Table 2. Geotechnical parameters for various mixtures [10].

\begin{tabular}{|c|c|c|c|c|c|c|c|c|c|c|}
\hline & & $0 / 100$ & $10 / 90$ & $20 / 80$ & $30 / 70$ & $40 / 60$ & $50 / 50$ & $60 / 40$ & $70 / 30$ & $80 / 20$ \\
\hline Unit weight & {$\left[\mathrm{kN} / \mathrm{m}^{3}\right]$} & 16.87 & 16.68 & 16.48 & 15.60 & 14.72 & 13.83 & 13.05 & 12.36 & 12.07 \\
\hline $\begin{array}{c}\text { Saturated } \\
\text { unit weight }\end{array}$ & {$\left[\mathrm{kN} / \mathrm{m}^{3}\right]$} & 20.43 & 20.11 & 19.79 & 19.05 & 18.33 & 17.62 & 16.39 & 16.39 & 16.01 \\
\hline $\begin{array}{c}\text { Permeability } \\
\text { coefficient }\end{array}$ & {$[\mathrm{m} / 24 \mathrm{~h}]$} & 8.64 & 7.52 & 6.41 & 5.30 & 4.19 & 3.08 & 1.97 & 0.86 & 0.86 \\
\hline $\begin{array}{c}\text { Effective } \\
\text { cohesion }\end{array}$ & {$[\mathrm{kPa}]$} & 0 & 0 & 0 & 0 & 0 & 0 & 2.6 & 5.5 & 8.8 \\
\hline $\begin{array}{c}\text { Effective } \\
\text { internal } \\
\text { friction } \\
\text { angle }\end{array}$ & {$\left[{ }^{\circ}\right]$} & 41 & 40 & 39.30 & 38.80 & 38.60 & 39.50 & 38.50 & 38 & 34.50 \\
\hline $\begin{array}{c}\text { Young's } \\
\text { module }\end{array}$ & {$[\mathrm{MPa}]$} & 36.50 & 34.50 & 32.50 & 30.50 & 28.50 & 26.50 & 24.50 & 22.50 & 20.50 \\
\hline $\begin{array}{c}\text { Poisson's } \\
\text { ratio }\end{array}$ & {$[-]$} & 0.25 & 0.25 & 0.25 & 0.25 & 0.25 & 0.25 & 0.25 & 0.25 & 0.25 \\
\hline Cementation & {$[\mathrm{kPa}]$} & 0 & 2.2 & 4.4 & 6.6 & 8.8 & 11 & 13.3 & 15.5 & 17.7 \\
\hline
\end{tabular}

\section{Numerical analysis}

As a first step numerical calculation of steady state flow through polish test dike and stability analysis were performed using Plaxis program. This sort of calculation was performed before and published in [7],[11]. Numerical model of the polish test dike is shown in Fig. 4.

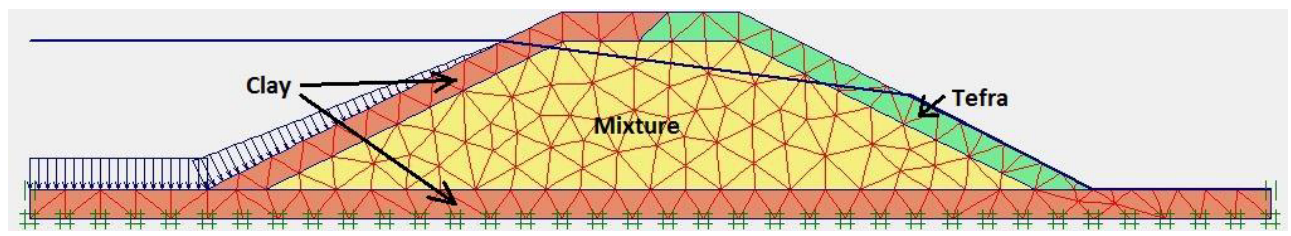

Fig. 4. Numerical model with FEM discretization of the polish test dike.

\subsection{Phi-c reduction calculation}

Phi-c reduction calculation process is an option in Plaxis software to compute safety factors. In this kind of calculation strength parameters of soil i.e. tangent of internal friction angle and cohesion are reduced step by step until failure occurs.

As a first step stability of the polish test dike was repeated with outcome of safety factor equal 2.667. This value is slightly different from values obtained in [7, 11] and the difference (about 10\%) is due to calculation method in other programs (SLIDE 5.0).

After preliminary calculation, the dike stability analysis for different mixture dredged material and ash bottom proportion were performed. The failure surface has similar form in all cases. The list of obtained safety factors are presented in Tab. 3 and Tab. 4. 
Table 3. Safety factors Msf for different mixtures.

\begin{tabular}{|c|c|c|c|c|c|c|c|c|c|}
\hline & $0 / 100$ & $10 / 90$ & $20 / 80$ & $30 / 70$ & $40 / 60$ & $50 / 50$ & $60 / 40$ & $70 / 30$ & $80 / 20$ \\
\hline $\begin{array}{c}\text { Safety } \\
\text { factor } \\
\text { Msf [-] }\end{array}$ & 2.02 & 1.98 & 1.96 & 1.95 & 1.94 & 1.97 & 2.33 & 2.67 & 3.20 \\
\hline
\end{tabular}

Table 4. Safety factors Msf for different mixtures after cementation process.

\begin{tabular}{|c|c|c|c|c|c|c|c|c|c|}
\hline & $0 / 100$ & $10 / 90$ & $20 / 80$ & $30 / 70$ & $40 / 60$ & $50 / 50$ & $60 / 40$ & $70 / 30$ & $80 / 20$ \\
\hline $\begin{array}{c}\text { Safety } \\
\text { factor } \\
\text { Msf [-] }\end{array}$ & 2.02 & 2.02 & 2.57 & 2.88 & 3.21 & 3.62 & 3.97 & 4.17 & 4.56 \\
\hline
\end{tabular}

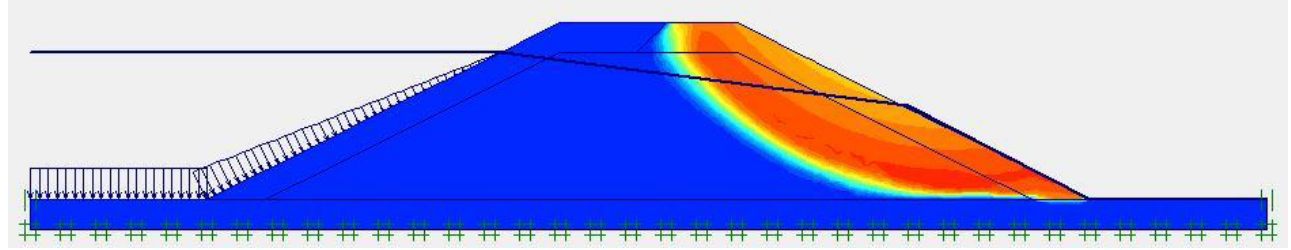

Fig. 5. Failure mechanism for the polish test dike for steady state flow.

\section{Conclusions}

All analysis proved dike slope stability according to minimum value of $\mathrm{Msf} \geq 1.3$ (and recommended value of $M s f \geq 1.5$ ). The Eurocode 7 requirements have also been met. It has to be mentioned that all calculations were performed for characteristic values. Cementation process highly increase slope dike stability. One of the most important characteristic of dredged material and coal combustion products mixture is its ability to cementing process which increase cohesion. The contribution of cohesion is more important from the other mixture parameters.

All the analysis were realized thanks to DredgDikes project (2011-2013) part-financed by EU funds (ERDF) in the frame of South Baltic Programme.

\section{References}

1. Polish Water Law 2005, Journal of Laws 05.239.2019

2. Polish Directive of the Ministry of Environment of 20 April 2007 on the technical requirements to be met by hydrotechnical structures and their location, Journal of Laws 07.86 .579

3. F. Saathoff, S. Cantré, Z. Sikora, Application of Dredged Materials, Coal Combustion Products and Geosynthetics in Dike Construction (2015)

4. EC 2000. European Waste Catalogue (EWC) 2000/532/EC

5. EN 1997-1. Eurocode 7 - Geotechnical design - Part 1: General rules (1997)

6. PN-EN 1997-1:2008. Eurokod 7 Projektowanie Geotechniczne, Polish national implementation of the Eurocode 7, $152 \mathrm{pp}$

7. L. Bałachowski, Stability of the Inner Slope of the Polish DredgDikes Research Dike at Stationary Flow, Proceedings of the South Baltic Conference on Dredged Materials in Dike Construction, Rostock: 105-110 (2014) 
8. R. Duszński, M. Cudny, Projekt stanowiska badawczego wału przeciwpowodziowego wykonanego z mieszanki urobku czerpalnego i popiołów. Politechnika Gdańska (2012)

9. L. Bałachowski, Z. Sikora, Mechanical properties of bottom ash - dredged material mixturs in laboratory tests. Studia Geotechnica et Mechanica, p. 3-11, Vol. XXXV, No. 3, 2013, Oficyna Wydawnicza Politechniki Wrocławskiej (2013)

10. S. Sorek, Analiza porównawcza stateczności wału wykonanego z różnych proporcji popiołu i refulatu, Master thesis, Gdańsk University of Technology, Gdańsk, (2015)

11. I. Pessato, Steady state and transient analysis of the flow through the test dike. Master thesis, University of Padova, Padova (2014)

12. Plaxis 8.2 manuals: www.plaxis.nl 